\title{
Bladder Disorder
}

National Cancer Institute

\section{Source}

National Cancer Institute. Bladder Disorder. NCI Thesaurus. Code C2900.

A non-neoplastic or neoplastic disorder affecting the urinary bladder. A representative example of non-neoplastic bladder disorder is bacterial bladder infection. A representative example of neoplastic bladder disorder is bladder carcinoma. 